\title{
The impact of the coronavirus pandemic on the insurance market of Uzbekistan and ways to develop funded life insurance
}

\author{
Dinora Baratova, Khayrullo Khasanov, Ikromjon Musakhonzoda, Shokhruh Abdumuratov, \\ and Khusniddin Uktamov
}

Tashkent State University of Economics, Tashkent, Uzbekistan

\begin{abstract}
This article puts the emphasis on the impact of the coronavirus pandemic on the Uzbek insurance market and ways to elaborate funded life insurance. In addition, analyzed international practice in the development of life insurance in the world is analyzed. Scientists and experts have also conducted research on the impact of the COVID-19 coronavirus pandemic on the insurance market of Uzbekistan. It worthy to note that the insurer is a specific entity operating under the laws of Uzbekistan, and the consumer can be real (with a life insurance policy) and potential (which can be insured under accumulative life insurance). The questionnaires developed by us for research purposes were divided into four groups, and a survey was conducted. In addition, the impact of inflation as an external factor, the rate of investment return arising from the results of the insurer's investment activities, was assessed. In addition, indicators on the mass of risk were offered for the insurer. Conclusions and recommendations were made on the impact of the coronavirus pandemic on the insurance market of Uzbekistan and ways to develop funded life insurance.
\end{abstract}

\section{Introduction}

Extensive work is being done in international practice to develop funded life insurance. The study focuses on the competition between commercial banks and insurance companies in majority of countries all over the world, particularly, in developing countries, to justify the benefits of directing free funds to insurance companies specializing in life insurance and developing tools and methods to increase interest in orientation. The results of many studies emphasize that the use of methods of calculating insurance amounts taking into account inflationary processes in the development of insurance products in countries with high inflation rates, is beneficial for both parties. Today, there is a situation where various types of financial instruments aimed at attracting temporarily vacant funds of citizens and enterprises and organizations create a competitive relationship between its suppliers, banks and insurance companies. However, in today's relatively high economic climate, the owners of these funds want to get their money back in the short term. In this regard, they are increasingly turning to banks. Therefore, insurance companies need to look for ways to ensure competitiveness, and to do this, first of all, focus on introducing participants to their advantages. 
In Uzbekistan, life insurance, and in particular accumulative life insurance, is developing only within the created benefits, and this insurance does not have a mass character among the population. As a result, compared to developed countries, the life insurance network has not been cope to play a consequential role in the social sphere and the economy as in these countries. There are many reasons for this, and it is of grand significance to analyze, study these reasons on a scientific basis and find solutions on this basis.

At the end of December 2019, the first coronavirus infection (COVID-19) was reported in Wuhan, the capital of China's Hubei Province, and the disease became widespread in many provinces of the country, other countries and continents. As of March 16, 2020, more than 170,000 people in 148 countries were reported to be infected with the virus. The government of our country has taken drastic measures to mitigate the negative impact of this pandemic on the economy. Particularly, in accordance with the Decree of the President of the Republic of Uzbekistan dated March 19, 2020 PD-5969, "On priority measures to mitigate the negative impact of the coronavirus pandemic and global crisis on macroeconomic stability in times of coronavirus infection and other global threats", to ensure the uninterrupted operation of industries and sectors of the economy, stimulate foreign economic activity, effective social support, prevent a sharp decline in incomes, the Anti-Crisis Fund was founded under the Ministry of Finance of the Republic of Uzbekistan in the amount of 10 trillion soums. 1]. Alternatively, the Republican Special Commission for the preparation of the Program of measures was established according to the Decree of the President. Several restrictions were penetrated. In particular, from March 23, 2020, the state borders were closed, all enterprises and institutions in Tashkent (regardless of the form of ownership) were allowed to go on vacation without affecting their main activities, the remaining workers could work as much as possible remotely (online or remotely). Furthermore, from March 16, 2020, air, rail and road services of Uzbekistan with foreign countries were suspended [2].

To state, the large-scale prevention of the COVID-19 pandemic in the country has led to a decline in international economic relations, tourism, hotel business, remittances, small businesses in production and services, and, consequently, a decrease in income. This situation has undoubtedly had a negative effect on the elaboration of the insurance market, one of the most important links in the economy, due to the decline in production at enterprises and organizations, the reduction of export-import operations and the decline in business activity, the forecast of insurance services was not met. As a result, the business plans of insurance companies operating in the insurance market of Uzbekistan for 2020 were revised [3].

Scientists and specialists have also conducted research on the impact of the COVID-19 coronavirus pandemic on the insurance market of Uzbekistan.

\section{Literature review}

At the end of the 19th century, such views emerged: "some saw the face of the debt category in insurance, others - friendship, others - savings, and fourth - the contract." Thus, the initiative to partially include this type of insurance in the credit category has been renewed. In this regard, H.A. Eisenstein wrote that life insurance is a special form of long-term savings, in which the insurance premium is "A simple fund that is accumulated in his personal account in the book of the insurance society, as in banks" [4].

The encyclopedic dictionary of F.A. Brockhaus and A.I. Efron defines the term "life insurance" as follows: the purpose of life insurance is to compensate for the material damage caused to his family members and relatives as a result of the untimely death of the person, it is to spend for a specific purpose after his death or to provide for the insured person in his old age." However, according to the proponents of the theory of damage distribution, there is uncertainty in the definition of the term "compensation for material damage" [5]. 
A different approach was put forward by the German scientist Gupka. He advanced the theory of the general supply of demand that could occur. Although the scientist's opinions and the notion of meeting the ultimate need for insurance are incredibly different, according to Serebrovsky: the purpose of the "supply" theory is to meet these requirements, focusing the centre of gravity on the initial period of insurance" [6]. "The theory of eventual demand" focuses on anticipating possible claims; focuses on the result of insurance, the purpose of the "supply" theory is to meet these requirements, focusing the centre of gravity on the initial period of insurance" [6].

Thus, contradictions have been identified in eventual demand theory, which are defined by the demand absence for material support in realizing the risk of death in life insurance (e.g., in the wealthy relatives of the deceased). The general theory of possible satisfying demand removes such a contradiction because the achievement of wealth known through life insurance does not contradict the stated primary purpose of insurance.

One of the most meaningful definitions given from a legal point of view is the definition given by A.G. Goyxbarg. This view demonstrates the compatibility of Gobby's theory of eventual demand with Gupka's theory of the general supply of demand that can occur [7].

The following views of T. Iminov and E. Kim are noteworthy: "The introduction of quarantine measures will lead to the closure of most large and small enterprises and the release of employees on unpaid leave. It, in turn, has a negative impact on the conclusion of new insurance contracts and the extension of existing ones." [8]

E.Abdullaev noted that "... The Agency for Development of the Insurance Market has developed a package of insurance products for insurance against coronavirus pandemic, vaccination, outpatient treatment to ensure the stability of incomes and budget savings" [9].

The research conducted by S.Nasretdinov and J.Jorabaev covers the activities of insurance companies during the coronavirus pandemic. According to the authors, in the Uzbek insurance market, mainly insurance of foreigners, property (buildings) insurance has partially decreased. Termination of flights and work regimes of employees and insurance agents in pandemic conditions[10].

\section{Materials and Methods}

As a result of strict quarantine restriction influx, according to preliminary data, in the first half of 2020, the gross domestic product of Uzbekistan in current prices amounted to 255 252.6 billion soums. And it was increased by $0.2 \%$ compared to January-June 2019. However, in January-June 2019, GDP growth was $6 \%$ compared to the corresponding period of 2018. Thus, in the first six months of 2020, GDP growth decreased by $5.8 \%$ compared to the corresponding growth rate of 2019 [11]. Furthermore, according to statistics, in the first quarter of 2020, the amount of insurance premiums on voluntary insurance amounted to 413.4 billion soums. However, this figure was 449.8 billion soums in the first quarter of 2019 , or 36.4 billion soums more than in the first quarter of 2020. In other words, the volume of insurance premiums collected by insurers of the country in the I quarter of 2020 decreased by $8 \%$ compared to the volume of insurance premiums collected in the I quarter of 2019 (Figure 1). For comparison: in the first quarter of 2019, the proliferation of insurance premiums on voluntary types of insurance was $142 \%$ compared to the corresponding figure in the first quarter of 2018 [12]. 


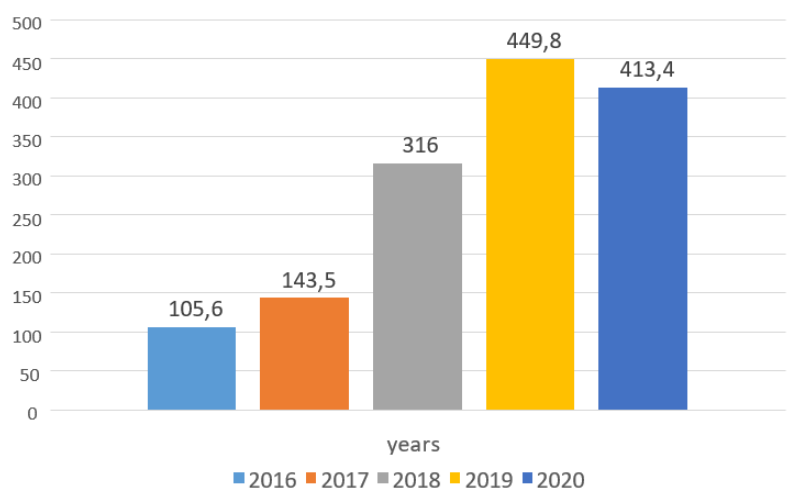

Fig. 1. Dynamics of insurance premiums accumulated on the insurance market of Uzbekistan in the I quarter of 2016-2020 (billion soums)

Due to the coronavirus pandemic, quarantine restrictions in Uzbekistan were officially introduced in the second half of March 2020. So, in January-February of this year, the national insurance market, as usual, continued to develop. However, the disruption of economic activity caused by the coronavirus pandemic in the country since the second half of March 2020 has had a negative impact on key indicators of the insurance market. Therefore, there is an aspect that needs to be debated here. Logically, given the introduction of quarantine restrictions in the country in the second half of March 2020 to ease the effects of the coronavirus pandemic, its negative impact in the first quarter of 2020 should not have had a significant impact on the insurance market of Uzbekistan. However, the data analysis presented in Figure 1 shows that the volume of insurance premiums on voluntary types of insurance decreased by $8 \%$ [13].

As it is evident from Figure 1, the volume of insurance premiums on voluntary insurance collected in the insurance market of Uzbekistan in the I quarter of 2019 exceeded the volume of insurance premiums on voluntary insurance collected in the I quarter of 2018 by 133.8 billion soums or an increase of $142 \%$. In the first quarter of 2018 , in contrast to the first quarter of 2017, the receipt of insurance premiums on voluntary types of insurance increased by $220 \%$. Based on this, the expert believes that if quarantine measures had not been presented owing to the coronavirus pandemic, perhaps by the end of the first quarter of 2020 , the amount of insurance premiums received on voluntary types of insurance would have increased by an average of $140 \%$ [14].

Pursuant to the results of the first quarter of 2016-2020, insurance companies running in the insurance market of the country made insurance payments in the amount of 550.5 billion soums to cover losses incurred by legal entities and individuals. Of this, 446.3 billion soums or $81.1 \%$ fell to voluntary insurance, the remaining $18.9 \%$ to compulsory insurance. It can also be seen from the data in the figure below (Figure 2) [15].

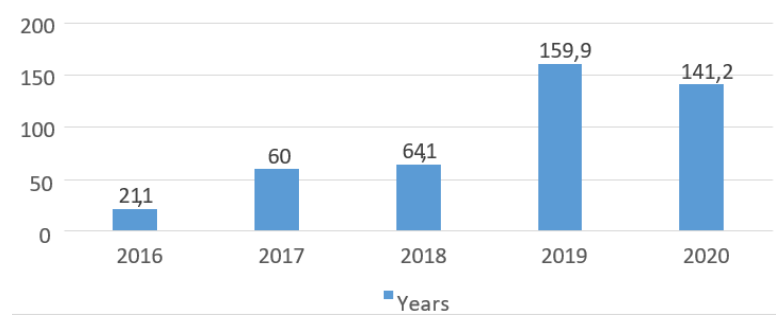

Fig. 2. Dynamics of insurance payments on the insurance market of Uzbekistan in the I quarter of 20162020 (billion soums) 
It is crystal clear from the data in Figure 2 that the largest insurance payments in the analyzed period were made in the first quarter of 2019, amounting to 159.9 billion soums. In the first quarter of 2020, the coronavirus infection had not spread, and even during this period, we could observe a significant increase in the volume of insurance payments. However, due to the COVID-19 pandemic, the amount of insurance payments in the first quarter of 2020 amounted to 141.2 billion soums, which is 18.7 billion soums or $12 \%$ less than in the first quarter of last year. However, insurers' volume of insurance payments in the first quarter of 2019 amounted to 95.8 billion soums more than in the first quarter of 2018 , boosting $249 \%$ [16].

In the first half of 2020, the insurance community of Uzbekistan in the media reported that even in the event of a coronavirus pandemic, insurance payments are made to cover the damage caused by insurance events. For example, the total liability of the insurance company "Kafolat" for the objects damaged by strong winds and rains in Bukhara region on April 27, 2020, amounted to 21.9 billion soums. soums, for a total of $195.1 \mathrm{mln}$. soums on 13 appeals. UZS was paid for insurance coverage. From April 6 to April 17, 2020, Uzbekinvest Insurance Company paid 132.9 million soums in insurance coverage.

The volume of insurance premiums decreased by $4 \%$ in the 1 st quarter of 2020 compared to the 1st quarter of 2019. However, this change had a different effect on all insurance products. While the insurance premium rate for one type of insurance fell, the amount of insurance premiums for another type remained unchanged.

Regarding the impact of the coronavirus pandemic, industry experts believe that the impact of the pandemic has reduced the demand for life insurance and the number of new insurance contracts that need to be concluded. As a result, the amount of insurance premiums under current insurance contracts has sharply decreased.

Briefly, it can be pinpointed that the restrictive quarantine measures introduced in the wake of the COVID-19 coronavirus pandemic have had a negative impact on the development of the insurance market, along with a sharp slowdown in economic activity. As a result, in the first quarter of 2020, there was a decrease in some indicators of the insurance market development in Uzbekistan. However, due to the forestallment of the spread of coronavirus infection, the elimination of cases of the virus, the production of vaccines capable of eradicating the virus and the implementation of mass vaccination, the economy will recover in the near future.

\section{Result and discussion}

The organizational and financial peculiarities of accumulative life insurance have necessitated a comprehensive review of methods that complement its content and assess the content of risks associated with this type of insurance. In this regard, we use the indicator "risk mass" used by scientists Yu.V. Rozhkov and L.P. Drozdovskaya, mentioned in the second part of the first chapter, to assess risk in cumulative life insurance. In accumulative life insurance, the quantitative magnitude of risks is determined by the indicator "risk mass". This indicator, expressed in monetary terms, allows a systematic analysis of the impact of internal and external economic factors on life insurance and the feasibility and effectiveness of savings processes. Overall, the proposed indicator calculation permits to analyze the correlation between the components and elements of the internal structure of the accumulation process and to make various verdicts in the accumulation process by the subjects of the insurance contract [19].

We will concentrate on at the micro level the method of calculation of the indicator "Risk mass" associating with the subjects of the insurance contract, the calculation of which is directed to a separate contract of accumulative life insurance. The results of the risk mass calculation permits us to determine the causes of the relationship between the gathered 
monetary resources, macroeconomic indicators and financial market indicators, and between the intermediate and final results of the process of accumulating life insurance of individuals. Moreover, we clarify change dynamics in the "risk mass". Finally, we suggest possible practical actions of insurance subjects contract on the management of the accumulative life insurance program.

The risk mass represents the monetary losses and the planned amount of savings for the insured, which may occur as a result of external economic (independent of the entity) and internal (dependent on the decisions of the entity) factors in the accumulation process during the term of the insurance contract.

External factors encompass the inflation's impact, the rate of return on investment resulting from the investment activities of the insurer. Internal factors include the insurer's acceptance or non-acceptance by the insured of particular product capabilities (with respect to annual indexation of the sum insured and premiums, changes in the sum insured, opening an additional investment account), the choice of investment strategy (in life investment insurance) [20].

The risk mass is comprised of two parts: the main (real), ie expressed in terms of the difference between financial liabilities and guarantees, and the virtual - additional investment income.

Hence, the risk mass for the insured consists of the real part (expressed as the discrepancy between the insurance premiums and the sum insured guaranteed by the insurer) and the expected investment income (virtual part). This indicator is a value indicator and assesses the risk in monetary terms and at any time based on the actual costs incurred and the expected return on investment. It can be represented by the following formula [21]:

$$
\mathrm{CPM}=\mathrm{TC} \text { TSB }-\mathrm{TCSS}+\sum \mathrm{KIDS}
$$

In this case:

$\mathrm{CPM}$ - risk mass for the insured,

$\sum$ TSB - paid insurance premium,

TCSS - the amount of insurance guaranteed by the insurer in the event of reaching a certain age or the risk of death,

$\sum$ KIDS - the amount of expected investment income.

The risk mass for the insurer reflects the volume of its liability to the insured and the monetary expression of losses that may occur due to the influence of external and internal factors during the term of the insurance contract.

External factors encompass macroeconomic factors: inflation, financial market indicators, return on investment, etc., and the death contingency of the insured or the insured during the term of the insurance contract. Internal factors include the availability of individual product options and their ability to be selected by the insured, the development of limiting conditions or supplementary opportunities for the accumulation process, the choice of areas for investing in insurance reserves, and more.

For the insurer, the risk mass also consists of the real part (in terms of the difference between the sum insured guaranteed by the insurer to the beneficiary and the insurance premiums actually paid by the insured) and the virtual (investment income amount) (virtual part) [22].

$$
\mathrm{CPM}=\mathrm{SOZHX}-\mathrm{CC} \text { SSB }+\sum \mathrm{KIDS}
$$

In this case: CPM - risk mass for the insurer,

SOZHX - the amount of liability guaranteed to the insured in the event of reaching a certain age or the risk of death,

$\sum \mathrm{SSB}$ - the amount of insurance premiums paid by the insured, 
$\sum$ KIDS - the amount of expected investment income.

In our example, a 25-year-old woman enters into a life insurance contract with a sum insured of 500,000 soums for a period of 20 years. The annual insurance premium, considering the risk level, is 28,000 soums. This accumulative life insurance product is developed based on a mixed life insurance program, which provides the insurer with an obligation to pay the sum insured and investment income in the event of the risk of death or old age, as well as "Exemption from insurance premiums" (insurance contract term). The continuation of the main Program in the event that the insured is permanently in a state of complete incapacity for work until the end of the term) [23].

In addition, the accumulative life insurance product provides for the right to annually index the sum insured and the insurance premium to protect the insurance supply from inflation and exchange rate fluctuations. The indexation value is set annually by the insurer based on the macroeconomic indicators for the current year, which may be lower than or equal to the central bank's refinancing rate. The right of indexation may also apply only for the first half of the insurance contract term, as agreed in the insurance contract. In our example, the indexation value is $10 \%$.

As external factors that may influence the accumulation process, we have adopted indicators of the inflation rate and the investment norm of contingency (minimum growth of savings guaranteed by the insurer). This indicator is measured considering the gross investment rate of return developed by the insurer on the results of investment activities. We equalized their oscillations over time in the calculation and recorded them in their sequences at 0.5 and 0.7 percent, respectively. The gained results permitted to track the development of the three cases and to determine the dynamics of the increase and decrease of the risk mass for the subjects of the insurance contract. Let's consider these cases in more detail [24].

The provided an sample is concrete and provides an overview of the essence and calculating method of this indicator. The calculation did not regard the contingency of annual changes in macroeconomic indicators, the error in the value of investment income, the impact of taxes and strict adherence to the methodology of calculation of mathematical reserves.

In this very study, the policyholder is a special entity operating under Uzbek laws and the consumer can be real (with a life insurance policy) and potential (which can be insured under accumulative life insurance).

The questionnaires developed by us for research purposes are divided into four groups:

The first group of questionnaires contained general questions (1-7), which allowed to determine the socio-economic characteristics of the respondents.

The second group allows to determine the insurance culture of the respondents (8-9) and to determine the preferences of the insurer based on territorial-classification characteristics.

The third group of questions (10-12) allows to determine the deposit choices of the respondents.

The fourth group of questions (13-15) allows to determine the characteristics of consumption in accumulative life insurance.

The second phase was carried out over a quarter of the survey, involving the respondents' families, friends, acquaintances, colleagues, and social media.

The final phase of the study consisted of analyzing the data obtained from the responses of the survey participants. Evaluation indicators were presented in the form of maximum and minimum scores of responses.

We analyze the responses received from the first group of questionnaires. Respondents socio-economic analysis delineated that $25.4 \%$ of those surveyed were male and $74.6 \%$ were female. The average age of men is 30 years, and the average age of women is 28 years. Of the total respondents, $78.2 \%$ are employees, $12.5 \%$ are entrepreneurs and managers, $9.3 \%$ are students and retirees. The main part of the survey was in the financial and credit sector, which accounted for $41.4 \%$, budget workers $24.3 \%$, manufacturing and industry $11.4 \%$, trade 
$7.8 \%$, services $7.9 \%$, domestic $5,1 \%$. The number of those employed in private practice was small, at $2.1 \%$. $52.5 \%$ of individuals have a monthly income of 1.5 million to 3 million soums, $24.1 \%$ of respondents receive a salary of 3 million to 5 million soums, $11.6 \%$ of individuals earn more than 5 million soums. $1.5 \mathrm{mln}$. those are earning less than $11.9 \%$. Of these, $3 \mathrm{mln} .74 .5 \%$ of those earning up to UZS 3 million are women. Men are earning more than UZS $65.4 \%$. Thus, the main part of the respondents is the economically active population, which allows assessing the consumer demand for accumulative life insurance.

The second group uses the respondents' responses to determine the insurance culture of the insured, their views on insurance and which insurance companies they prefer. $54.1 \%$ of respondents are users of insurance services, of which $60 \%$ are men and $40 \%$ are women. Thus, more than half of those surveyed say they need insurance services.

We analyze the marital status of respondents, the availability of children, age and propensity to insurance in terms of income.

The majority of those over the age of 30 admit to the need for insurance, with $73.4 \%$ of those aged 31 to 54 and $77.5 \%$ of those aged 55 and older. $52.5 \%$ of those aged 23 to 30 have a tendency to purchase insurance policies (see Table 1). After analyzing the data, it may be deduced that there is a relationship between age and propensity to insure.

Table 1. Relationship between people's propensity for insurance by age.

\begin{tabular}{|l|l|l|l|}
\hline \multirow{2}{*}{ Age } & Number of respondents & \\
\cline { 2 - 4 } & Tendency to insure & No inclination to insurance & Total \\
\hline $20-22$ & 48 & 104 & 152 \\
\hline $23-30$ & 337 & 304 & 641 \\
\hline $31-54$ & 130 & 47 & 177 \\
\hline Over 55 years old & 31 & 9 & 40 \\
\hline Total & $\mathbf{5 4 6}$ & $\mathbf{4 6 4}$ & $\mathbf{1 0 1 0}$ \\
\hline
\end{tabular}

There is also a correlation between people's marital status and the availability and number of children, which can be spotted from the information in the table below (see Table 2). At the same time, the presence of children was more prone to insurance than marital status.

Table 2. Interdependence on people's marital status and the availability of children.

\begin{tabular}{|c|c|c|c|c|c|c|c|}
\hline \multirow{2}{*}{$\begin{array}{l}\text { Family } \\
\text { condition }\end{array}$} & \multicolumn{3}{|c|}{ Respondents, (person) } & \multirow{2}{*}{$\begin{array}{l}\text { Children } \\
\text { presence }\end{array}$} & \multicolumn{3}{|c|}{ Respondents, (person) } \\
\hline & yes & No & total & & yes & No & total \\
\hline married & 281 & 200 & 481 & yes & 218 & 123 & 341 \\
\hline unmarried & 265 & 264 & 529 & No & 328 & 341 & 669 \\
\hline Total & 546 & 464 & 1010 & total & 546 & 464 & 1010 \\
\hline
\end{tabular}

However, the propensity is caused more by the adequacy of the financial opportunity than by the above factors. As people's financial capacity increases and their property increases, they tend to use insurance services more (see Table 3).

Table 3. The relationship between people's income levels and their propensity for insurance

\begin{tabular}{|l|l|l|l|}
\hline \multirow{2}{*}{ Income level } & \multicolumn{3}{|l|}{ Number of respondents, person } \\
\cline { 2 - 4 } & yes & No & total \\
\hline 1.5 mln. less than UZS & 40 & 80 & 120 \\
\hline 1.5 mln. from soums - 3 mln. up to UZS & 266 & 264 & 530 \\
\hline 5 million soums up to UZS & 148 & 95 & 243 \\
\hline 5 mln. higher than UZS & 92 & 25 & 117 \\
\hline Total & $\mathbf{5 4 6}$ & $\mathbf{4 6 4}$ & $\mathbf{1 0 1 0}$ \\
\hline
\end{tabular}

Of course, this law seeks to increase the financial capacity of a person to buy various types of property, use quality medical services, get education, travel, improve housing conditions, and concomitantly, reduce the risk of losses in these areas. 
On the basis of these it can be concluded that his age and income primarily influence a person's propensity to insure. Marital status and the presence or absence of children seem to have less impact on the propensity for insurance.

Table 4. The correlation between marital status and the presence of children and the propensity to save.

\begin{tabular}{|c|c|c|c|c|c|c|c|}
\hline \multirow{2}{*}{$\begin{array}{l}\text { Family } \\
\text { condition }\end{array}$} & \multicolumn{3}{|c|}{ Number of respondents, person } & \multirow{2}{*}{$\begin{array}{l}\text { Children } \\
\text { presence }\end{array}$} & \multicolumn{3}{|c|}{ Number of respondents, person } \\
\hline & yes & No & total & & yes & No & total \\
\hline married & 321 & 160 & 481 & yes & 242 & 99 & 341 \\
\hline unmarried & 337 & 192 & 529 & No & 416 & 253 & 669 \\
\hline Total & 658 & 352 & 1010 & total & 658 & 352 & 1010 \\
\hline
\end{tabular}

Let us now consider the effect of the above factors on individuals' tendency to accumulate and accumulate. According to the survey, $65.1 \%$ of respondents are saving a portion of their earnings. This figure was $78.2 \%$ for men and $60.7 \%$ for women. Married individuals and children accounted for $66.7 \%$ of men and $71 \%$ of women on this indicator (see Table 3.4 ). The presence of children seems to create a greater tendency to accumulate. But this factor is not much different from the marital factor.

Table 5. The correlation between a person's age and income level.

\begin{tabular}{|l|l|l|l|l|l|l|l|}
\hline \multirow{2}{*}{ Age } & \multicolumn{2}{|l|}{$\begin{array}{l}\text { Number of respondents, } \\
\text { person }\end{array}$} & Income level & \multicolumn{3}{l|}{$\begin{array}{l}\text { Number of respondents, } \\
\text { person }\end{array}$} \\
\cline { 2 - 4 } \cline { 5 - 7 } & yes & no & total & & yes & no & total \\
\hline $20-22$ & 80 & 72 & 152 & 1.5 mln. less than UZS & 14 & 106 & 120 \\
\hline $23-30$ & 425 & 216 & 641 & $\begin{array}{l}1.5 \text { mln. from soums }-3 \\
\text { mln. up to UZS }\end{array}$ & 342 & 188 & 530 \\
\hline $31-54$ & 129 & 48 & 177 & $\begin{array}{l}3 \text { mln. 5 million soums up to } \\
\text { UZS }\end{array}$ & 200 & 43 & 243 \\
\hline $\begin{array}{l}\text { Above } \\
55\end{array}$ & 24 & 16 & 40 & 5 mln. higher than UZS & 102 & 15 & 117 \\
\hline Total & 658 & 352 & 1010 & Total & 658 & 352 & 1010 \\
\hline
\end{tabular}

In humans, the tendency to accumulate increases as the income of oneself and one's family increases (see Table 5). It involves raising funds for the purchase of valuables, cars and real estate, and future purposes. In this case, the influence of age on the change in a person's propensity to save is insignificant. When a person's financial situation improves, the tendency to save also increases [24].

Surveys conducted to determine the relationship between a person's social status and propensity to save found that employees were more prone to be insured and that those employees were more likely to be insured than managers. It can be clarified by the fact that their understanding of insurance is adequate (see Table 6).

Table 6. The relationship between a person's social status and propensity to accumulate.

\begin{tabular}{|l|l|l|l|}
\hline \multirow{2}{*}{ Social status } & \multicolumn{3}{|l|}{ Number of respondents, person } \\
\cline { 2 - 4 } & yes & no & total \\
\hline Reads (student, doctoral student) & 13 & 66 & 79 \\
\hline Does not work (pension, decree, etc.) & 0 & 15 & 15 \\
\hline It works & 539 & 251 & 790 \\
\hline Entrepreneur & 26 & 7 & 33 \\
\hline Leader & 80 & 13 & 93 \\
\hline Total & 658 & 352 & 1010 \\
\hline
\end{tabular}

Independent funds are the most necessary instrument of accumulation, regardless of the amount of income (a savings instrument that does not incur additional income). This tool is the most ordinary one and does not entail special capabilities and knowledge, so this type of 
savings is 3.5 million. soums are of more interest among those surveyed with income (see Table 7). Additionally, as income boosts, so does the variety of instruments bestowed.

All participants who did not make a deposit at the time of the survey, but stated that they intended to save in the future, stated that they would put their savings in a bank deposit and an independent fund (see Table 8). 13 percent of participants had difficulty answering.

Thus, based on the absolute majority of the forms of accumulation (real and future) selected by the respondents, the demand ranking for the instruments of accumulation was as follows [25]:

1st place - independent accumulation;

2nd place - bank deposit;

3rd place - real estate purchase;

4th place - accumulative pension fund;

5 th place - purchase of gold and other precious metals;

6th place - the purchase of accumulative life insurance policy;

7 th place - buying stocks, currency, etc.

Table 7. Instruments used to make savings in conditions of different income levels

\begin{tabular}{|l|c|c|c|c|}
\hline \multirow{2}{*}{ Accumulation tools } & \multicolumn{4}{|l|}{ Respondents' proportion,\% } \\
\cline { 2 - 5 } & \multicolumn{3}{|l|}{ Monthly income } \\
\cline { 2 - 5 } & $\begin{array}{l}\mathbf{1 . 5} \text { mIn. less } \\
\text { than UZS }\end{array}$ & $\begin{array}{l}\text { 1.5 million to 3.5 } \\
\text { million. up to UZS }\end{array}$ & $\begin{array}{l}\mathbf{3 . 5} \text { mIn. and 5 } \\
\text { mln. up to UZS }\end{array}$ & $\begin{array}{l}\text { 5 mln. higher } \\
\text { than UZS }\end{array}$ \\
\hline Bank deposits & 40 & 31 & 56 & 83 \\
\hline $\begin{array}{l}\text { Accumulative life insurance } \\
\text { policy }\end{array}$ & 0 & 3 & 12 & 21 \\
\hline Focus on valuables & 0 & 0 & 4 & 0 \\
\hline Buying real estate & 0 & 15 & 4 & 29 \\
\hline Accumulative pension fund & 0 & 24 & 24 & 29 \\
\hline Independent fund & 64 & 55 & 12 & 42 \\
\hline $\begin{array}{l}\text { Financial instruments (MB, } \\
\text { currency, shares, etc.) }\end{array}$ & 0 & 5 & 28 & 21 \\
\hline
\end{tabular}

Responds to the Group 3 questions led to the conclusion that there was a problematic situation formed from the participants' opinions on savings and insurance. In our opinion, this indicates that the traditions of insurance in Uzbekistan have not yet fully penetrated into the understanding of members of society, the population has insufficient understanding of the savings and consumption characteristics of life insurance, shortage of confidence in longterm savings instruments. Hence, people represent a preference for other short and liquid forms of savings, such as bank deposits and independent savings.

Table 8. Savings instruments that plan to accumulate at different levels of income

\begin{tabular}{|c|c|c|c|c|}
\hline \multirow[t]{3}{*}{ Accumulation tools } & \multicolumn{4}{|c|}{ Percentage of respondents, $\%$} \\
\hline & \multicolumn{4}{|c|}{ Monthly income } \\
\hline & $\begin{array}{l}1.5 \text { mln. less } \\
\text { than UZS }\end{array}$ & $\begin{array}{l}1.5 \text { million to } 3.5 \\
\text { million. up to UZS }\end{array}$ & $\begin{array}{l}3.5 \mathrm{mln} \text {. and } 5 \\
\text { mln. up to UZS }\end{array}$ & $\begin{array}{l}5 \text { mln. higher } \\
\text { than UZS }\end{array}$ \\
\hline Bank deposits & 27 & 46 & 27 & 0 \\
\hline $\begin{array}{l}\text { Accumulative life insurance } \\
\text { policy }\end{array}$ & 0 & 8 & 0 & 5 \\
\hline Focus on valuables & 0 & 4 & 0 & 12 \\
\hline Buying real estate & 48 & 54 & 0 & 56 \\
\hline Accumulative pension fund & 13 & 10 & 0 & 14 \\
\hline Independent fund & 41 & 38 & 83 & 0 \\
\hline $\begin{array}{l}\text { Financial instruments } \\
\text { currency, shares, etc.) }\end{array}$ & 0 & 25 & 0 & 23 \\
\hline
\end{tabular}

Participants ' responses were divided across all response options when we analyzed the reasons for concluding or rejecting a funded life insurance contract (see Table 9). The majority of respondents, however, who did not long to purchase a funded life insurance 
policy, also cited the following as the most requisite criteria for life insurance: affordability of the insurance policy, the guarantee of insurer reliability and simple insurance product look ( specific terms are not applied in insurance rules and insurance contracts).

Table 9. The composition of the reasons for concluding or denying a funded life insurance contract

\begin{tabular}{|l|l|l|}
\hline Answer option & Number of respondents, person & Share, \% \\
\hline I have a life insurance policy & 89 & 8,8 \\
\hline Yes, I plan to take the police & 136 & 13,5 \\
\hline Yes, but the terms offered are not satisfactory & 73 & 7,2 \\
\hline Yes, but I can't buy it because it's expensive & 75 & 7,4 \\
\hline No, this is an expensive product & 71 & 7,0 \\
\hline No, this is not an effective way to put money & 155 & 15,3 \\
\hline I have never heard of this instrument & 103 & 10,2 \\
\hline I don't want to & 283 & 28,0 \\
\hline No, because I don't trust insurers & 25 & 2,5 \\
\hline Total & 1010 & 100 \\
\hline
\end{tabular}

$21 \%$ of men and $26 \%$ of women wanted satellite insurance services as well. Such services include medical services, legal support of insurance contracts, call centers and others.

Pursuant to the survey, it can be deduced that the results of the survey are consistent with the results of international research presented in the second section of the second chapter of this dissertation. The rationale for low consumer demand are issues that are common to both research objects, such as rationally limited demand, psychological and behavioral confidence. Again, two reasons can be cited as reasons for the low demand for life insurance, such as a lack of understanding of the characteristics of the life insurance product to be accumulated and a trust lack in insurers. However, it should be noted that many potential insurers cannot decide on the contract without a good understanding of the advantages of life insurance and its need for them [26].

Summarizing the survey results, we concluded that the factors that ensure the formation of demand for savings life insurance are as follows.

1. Accumulated life insurance products must be compatible with a person's life processes. That is, people get married when they are young, educated in school and then in secondary special or higher education institutions, and then their income opportunities expand, and in turn, their interest in protecting that income increases. So now they are thinking more about real estate, buying different household appliances and cars to improve the family's social conditions, educating the children as they grow up, and raising funds for weddings, thinking about the children's future. Then, as they approach retirement age, they try to accumulate savings for retirement.

2. Positive events in a person's life, such as the birth of a child, moving to a new job, career growth, buying real estate, buying a car, etc., are situations that attract the purchase of accumulative life insurance products on their special terms.

3. Individual attitudes towards risk and liability play a special role in people's insurance culture. People who live a healthy lifestyle (do not smoke, do not drink alcohol and do not engage in various other health and spiritually harmful habits) are far from various risks, and they think about saving more. People with a high sense of responsibility for those whose lives and activities depend on them (family members or dependents) are concerned that those who depend on them may become ill or disabled, encouraging them to take out life insurance for themselves and the people under their responsibility.

4. Accumulated life insurance also covers several partially related risks to social security and social insurance. The global trend in this regard is that the state and employers are putting the financial responsibility for such risks on the shoulders of more individuals. In this case, this type of insurance assumes this burden. 
5. Other factors affecting insurance decisions: recommendations of pecuniary advisers, recommendations of family, recommendations of friends and acquaintances and colleagues, conclusions about the death of a loved one in an accident, the results of other accidents, world events and catastrophes and so on.

6. Creating interest in life insurance is accumulated in insurers' potential insurers using marketing tools rather than advertising. Meanwhile, the use of innovations to change the design of products and carry out explanatory work among people serves to change their attitude towards insurance.

As mentioned earlier, the purpose of diagnosing consumer demand is to develop recommendations for increasing consumer demand for individuals' accumulative life insurance.

\section{Conclusions}

The above goals can be achieved through the effective implementation of life insurance in the example of developed countries. With this in mind, the government of Uzbekistan puts a consequential heed to insurance elaboration. However, this insurance network has not developed to today's level. Therefore, it requires in-depth research in this area.

The following conclusions were drawn during the study of the monograph:

1. In the nineteenth and twenty-first centuries, the content and economic significance of life insurance in economics have been improved and expanded based on defining its genesis, broadening the understanding of this insurance, defining its organizational and financial features.

2. Accumulative life insurance is a unique type of insurance based on the doctrine of dualism, the belief in longevity in the event of a sudden death at any stage of a person's life.

3. Accumulated life insurance is related to the negative and positive circumstances in the lives of individuals (insured and insured persons). It is concentrated on the principles of payment (insurance premium), return (insurance coverage), maturity (insurance period), profitability (the additional investment income) is a type of insurance aimed at protecting their property interests.

4. Mobile life insurance is determined by the accumulation of insurance amounts during the entire insurance term contract. Consequently, it is based on people's tendency to save (save their funds) and earn investment income.

5. Life insurance in Uzbekistan and accumulative life insurance has significantly lower rates than in developed and many developing countries.

6 . In recent years, our country has made some progress in life insurance, and this growth is mainly due to tax benefits provided by the government for long-term life insurance.

7. The main reasons for the low level of life insurance in Uzbekistan compared to these types of insurance in many countries are high inflation and devaluation in the economy, relatively low incomes, insurance companies' inexperience, and low-income public confidence in insurance services.

8. Given that the main source of income of an insurance company engaged in accumulative life insurance is the income from the investment of accumulated insurance premiums, the lack of profitable investment instruments in Uzbekistan slows down this type of development insurance.

9. The fact that the insurance legislation of Uzbekistan does not allow abroad insurance companies to operate in the national market limits the possibility of direct study of the experience of advanced foreign insurance companies.

10. The level of competition in the national insurance market of Uzbekistan is relatively low. Allowing abroad insurance companies to operate in the domestic market will lead to increased competition in the market. 
11. An insurance company needs to ensure data transparency for policyholders to increase its clientele. To do this, insurance companies must first and foremost provide insurance services, indicators of their financial stability and other information on time and in a manner that is easy to use in attracting potential policyholders. But so far, insurance companies have not created the necessary conditions for the insured. In order to eliminate this shortcoming, it is necessary to establish by law that insurance companies publish information related to their activities on time and to establish a procedure for imposing fines on insurance companies that do not comply with the required level.

12. So as to proliferate the level of profitability of investment activities of national insurance companies, insurance companies must ensure the transparency of information on their investment opportunities through their websites. In addition, it will create opportunities for entities in need of investment funds to meet their investment needs while expanding the choice of investment recipients for insurance companies.

13. General, statistical and analytical data on the insurance market of Uzbekistan are not published sufficiently and on time. The lack of timely and complete disclosure of such data makes it difficult to research the field and identify problems on time. Hence, it is paramount to entrust this task to the "Insurance Market Development Agency" or "Association of Professional Participants of the Insurance Market of Uzbekistan" to determine the means of control over its implementation and create a separate site for the publication of such information.

14. In the context of high inflation, in order to procure the conclusion of long-term (five years and more) accumulative life insurance contracts, as well as taking into account the differences in income levels of people at various phases of life (increasing or decreasing insurance premiums at the discretion of the insured) It is crucial to elaborate and offer insurance products, which are calculated in the form of) and linked to a fixed exchange rate.

15. In order to popularize life microinsurance, the development of standard rules for the use of this type of insurance, including the organization of insurance of the poor based on public-private partnership, will give the desired result.

\section{References}

1. Decree of the President of the Republic of Uzbekistan No. PD-5969 of March 19, 2020 2 .

2. Decree of the President of the Republic of Uzbekistan dated January 29, 2020 No. F5537

3. Resolution of the President of the Republic of Uzbekistan "On measures to further reform and develop the insurance services market", April 10, 2007.

4. D. J. Keynes. Progress, 19 (2019)

5. Kh. F. Uktamov, International Journal of Modern Agriculture, 10 (2021)

6. D. Bland. Insurance: Principles and Practice, The Chartered Insurance Institute, 93 (2020)

7. K. G. Voblyy, Fundamentals of Economics of Insurance, 35 (2018)

8. G. F. Shershenevich, Course of law, 66 (2003)

9. V. V. Shaxov, Finance and Statistics, 24 (2003)

10. V. V. Shaxov, Insurance, 55 (2003)

11. N. G. Adamchuk. Theory and practice of insurance, 70 (2003)

12. I. M. Shvetsova, Dissertation for the candidacy of a candidate of economic sciences. Moscow, 43 (2018) 
13. N. Kh. Jumaev, E. M. Maksumov, Iqtisod-Moliya, 35 (2020)

14. N. P. Saxirova, Prospect, 72 (2007)

15. Chernova G.V. Welby, Prospekt, 15 (2007)

16. I. Kh. Boev, Finance Environment, 45 (2007)

17. S. V. Ermasov, N. B. Ermasova, Higher education, 54 (2008)

18. R. Korjev, Accounting, 76 (2008)

19. D. M. Abdusattorova, The basis of business, 33 (2009)

20. Kh. M. Shennaev, Finance and economics, 24 (2013)

21. U.V. Semyonova, Physical Accumulation, 44 (2014)

22. M. A. Mirsadykov, Banks Accosiation, 24 (2014)

23. E. V. Semenova, Author's abstract on dissertation, 41 (2014)

24. I. Abduraxmonov, Economics and Finance, 32 (2018)

25. O. Yuldashev, Sh. Zakirkhodjaeva, Economics and Finance, 24 (2019) 